\title{
ACCUMULATION OF HEAVY METALS IN PLANTAGO MAJOR GROWN IN URBAN AND POST-INDUSTRIAL AREAS
}

\author{
LEVENTE LEVEI ${ }^{a, b}$, ENIKO KOVACS ${ }^{a}$, MARIA-ALEXANDRA HOAGHIA ${ }^{a}$, \\ ALEXANDRU OZUNU ${ }^{\text {b, }}$
}

\begin{abstract}
The enrichment and accumulation of heavy metals $(\mathrm{Cu}, \mathrm{Pb}, \mathrm{Zn}$, $\mathrm{Cd}, \mathrm{Cr}, \mathrm{Ni}$ ) in Plantago major leafs was comparatively studied in an urban (Cluj-Napoca) and a post-industrial area (Baia-Mare) from Romania. These two sites were selected for study as in Cluj-Napoca the dominant metal pollution sources are related to traffic, urban runoff, residential heating and municipal landfill, while in Baia-Mare the main pollution sources are the former ore processing activities and the remaining metal rich mining wastes. The average concentrations of $\mathrm{Zn}$ and $\mathrm{Pb}$ were higher in the soils collected from the postindustrial area, while the $\mathrm{Cr}$ and $\mathrm{Ni}$ in those from the urban area. The $\mathrm{Cu}, \mathrm{Cd}$, $\mathrm{Cr}$ and $\mathrm{Ni}$ in plantain leafs were comparable in both areas, while $\mathrm{Pb}$ and $\mathrm{Zn}$ were higher in the post-industrial area. Based on the enrichment factor and the metal accumulation index, plantain was found to be tolerant to high metal contents and moderate accumulator of $\mathrm{Cu}$ and $\mathrm{Zn}$.
\end{abstract}

Keywords: Plantago major, heavy metal, soil, enrichment factor.

\section{INTRODUCTION}

As a result of emissions from mining, industry, combustion of fossil fuels, road traffic and other human activities high loads of heavy metals (HMs) are released into the environment, affecting living organisms and the quality of soil, water and air. They can be naturally found in soils, but barely at harmful levels [1, 2]. Although the definition of $\mathrm{HMs}$ is still under debate [3-5], we use this term to refer to $\mathrm{Cu}, \mathrm{Pb}, \mathrm{Zn}, \mathrm{Cd}, \mathrm{Cr}$ and $\mathrm{Ni}$. These metals are generally associated with environmental pollution and have adverse effects on plants in high amounts of bioavailable forms.

\footnotetext{
a INCDO-INOE 2000 Research Institute for Analytical Instrumentation, 67 Donath str., RO400293, Cluj-Napoca, Romania.

b Babeş-Bolyai University, Faculty of Environmental Sciences and Engineering, 30 Fantanele str., RO-400294, Cluj-Napoca, Romania.

* Corresponding author: alexandru.ozunu@ubbcluj.ro
} 
Over the years, mining activities altered the landscape and highly affected the environment due to the extensive quantity of waste materials. Soil is not only a pollution receptor, but also a potential secondary source of contamination for the ecosystem [6]. This occurs through the accumulation and diffusion of $\mathrm{HMs}$ or other contaminants during their bio-chemical and physical interactions with the soil [7]. High levels of HMs in urban areas are brought about by traffic, which is becoming an increasing issue globally. Urban agglomerations are both sources and receptors for pollutants. Emissions from traffic are comprised of gaseous pollutants that also accumulate in the air and after deposition affect roadside soils and plants [8].

HMs negatively affect plants physiology especially by reducing their growth and interfering with the photosynthesis processes [9]. There are several plant species that developed various mechanisms (exclusion, accumulation, tolerance, translocation) to cope with high contents of HMs. The ability of plants to accumulate HMs can be used to monitor soil pollution [10]. The herbaceous plants potential to be used as bioindicators or biomonitors was identified and evaluated by many studies $[10,11]$. Among the most used species are dandelion (Taraxacum officinale), nettle (Urtica dioica) and plantain (Plantago major) [10, 12]. Among the herbaceous plants, Plantago major (plantain) is one of the most efficient bioindicators of $\mathrm{HMs}(\mathrm{Cu}, \mathrm{Zn}, \mathrm{Mn}, \mathrm{Pb}$, $\mathrm{Cr}, \mathrm{Pd}$ ) pollution. It absorbs and accumulates metals, has tolerance for high metal levels, metal concentration in plant tissues correlates well with the soil and air pollution levels and it is easily identifiable and quite common in various ecoregions [13-15].

In this study, the accumulation of $\mathrm{HMs}(\mathrm{Cu}, \mathrm{Pb}, \mathrm{Zn}, \mathrm{Cd}, \mathrm{Cr}, \mathrm{Ni})$ in plantain leafs collected from an urban (Cluj-Napoca) and a post-industrial (Baia-Mare) area was assessed by using the enrichment factor (EF) and the metal accumulation index (MAl).

\section{RESULTS AND DISCUSSION}

The limit of detection (LOD), limit of quantification (LOQ) and expanded uncertainty $(U)$ of the HMs determination method in soil and leafs are summarized in Table 1.

Table 1. Analytical method performance data

\begin{tabular}{|c|c|c|c|c|c|c|}
\hline \multirow{2}{*}{ HMs } & \multicolumn{2}{|c|}{$\begin{array}{c}\text { Limit of detection } \\
\text { (mg/kg) }\end{array}$} & \multicolumn{2}{c|}{$\begin{array}{c}\text { Limit of quantification } \\
\text { (mg/kg) }\end{array}$} & \multicolumn{2}{c|}{$\begin{array}{c}\text { Uncertainty } \\
\text { (\%) }\end{array}$} \\
\cline { 2 - 7 } & Soil & Leafs & Soil & Leafs & Soil & Leafs \\
\hline $\mathrm{Cu}$ & 0.10 & 0.02 & 0.30 & 0.06 & 10.2 & 10.6 \\
\hline $\mathrm{Pb}$ & 0.05 & 0.01 & 0.15 & 0.03 & 8.9 & 9.2 \\
\hline $\mathrm{Zn}$ & 0.06 & 0.01 & 0.18 & 0.03 & 9.2 & 9.6 \\
\hline $\mathrm{Cd}$ & 0.03 & 0.006 & 0.09 & 0.018 & 10.4 & 10.6 \\
\hline $\mathrm{Cr}$ & 0.05 & 0.01 & 0.15 & 0.03 & 9.0 & 10.2 \\
\hline $\mathrm{Ni}$ & 0.05 & 0.01 & 0.15 & 0.03 & 8.6 & 9.8 \\
\hline
\end{tabular}


Table 2. Recovery, certified and measured concentrations for CRMs

\begin{tabular}{|c|c|c|c|}
\hline HMs & $\begin{array}{c}\text { Certified } \\
\text { (mg/kg) }\end{array}$ & $\begin{array}{c}\text { Measured } \\
\text { (mg/kg) }\end{array}$ & Recovery (\%) \\
\hline \multicolumn{4}{|c|}{ ERM-CC141 Loam soil CRM } \\
\hline $\mathrm{Cu}$ & $12.4 \pm 0.9$ & $12.0 \pm 1.2$ & 97 \\
\hline $\mathrm{Pb}$ & $32.2 \pm 1.4$ & $31.6 \pm 2.8$ & 98 \\
\hline $\mathrm{Zn}$ & $50 \pm 4$ & $52 \pm 4.8$ & 104 \\
\hline $\mathrm{Cd}$ & $0.25 \pm 0.04$ & $0.23 \pm 0.02$ & 92 \\
\hline $\mathrm{Cr}$ & $31 \pm 4$ & $32 \pm 2.9$ & 103 \\
\hline $\mathrm{Ni}$ & $21.9 \pm 1.6$ & $22.2 \pm 1.9$ \\
\hline \multicolumn{4}{|c|}{ IAEA-359 Cabbage } \\
\hline $\mathrm{Cu}$ & $5.67 \pm 0.18$ & $5.35 \pm 0.57$ & 94 \\
\hline $\mathrm{Pb}$ & - & - & - \\
\hline $\mathrm{Zn}$ & $38.6 \pm 0.7$ & $37.9 \pm 3.6$ & 98 \\
\hline $\mathrm{Cd}$ & $0.12 \pm 0.005^{*}$ & $0.11 \pm 0.01$ & 92 \\
\hline $\mathrm{Cr}$ & $1.3 \pm 0.06^{*}$ & $1.3 \pm 0.13$ & 100 \\
\hline $\mathrm{Ni}$ & $1.05 \pm 0.05^{*}$ & $1.00 \pm 0.10$ & 95 \\
\hline
\end{tabular}

*Indicative values

Table 3. Heavy metal contents in soil $(\mathrm{mg} / \mathrm{kg})$

\begin{tabular}{|c|c|c|c|c|c|c|c|}
\hline Sample & $\mathbf{C u}$ & $\mathbf{P b}$ & \multicolumn{2}{c|}{$\mathbf{Z n}$} & $\mathbf{C d}$ & $\mathbf{C r}$ & $\mathbf{N i}$ \\
\hline \multicolumn{7}{|c|}{ Urban area (Cluj-Napoca) } \\
\hline S1 & 54.0 & 76.6 & 151 & 3.00 & 37.6 & 38.8 \\
\hline S2 & 30.2 & 23.3 & 83.9 & 3.30 & 71.1 & $\mathbf{7 5 . 9}$ \\
\hline S3 & 30.4 & 44.3 & 117 & 2.30 & 36.1 & 41.8 \\
\hline S4 & 25.1 & 33.1 & 95.4 & 3.30 & 46.3 & 55.6 \\
\hline S5 & 71.0 & 54.0 & 145 & 2.70 & 42.9 & 34.4 \\
\hline S6 & 35.1 & 87.2 & 156 & 3.90 & 41.8 & 38.3 \\
\hline Minimum & $\mathbf{2 5 . 1}$ & $\mathbf{2 3 . 3}$ & $\mathbf{8 3 . 9}$ & $\mathbf{2 . 3 0}$ & $\mathbf{3 6 . 1}$ & $\mathbf{3 4 . 4}$ \\
\hline Maximum & $\mathbf{7 1 . 0}$ & $\mathbf{8 7 . 2}$ & $\mathbf{1 5 6}$ & $\mathbf{3 . 9 0}$ & $\mathbf{7 1 . 1}$ & $\mathbf{7 5 . 9}$ \\
\hline Average & $\mathbf{4 1 . 0}$ & $\mathbf{5 3 . 1}$ & $\mathbf{1 2 5}$ & $\mathbf{3 . 0 8}$ & $\mathbf{4 6 . 0}$ & $\mathbf{4 7 . 5}$ \\
\hline St. Dev. & $\mathbf{1 7 . 8}$ & $\mathbf{2 4 . 8}$ & $\mathbf{3 0 . 6}$ & $\mathbf{0 . 5 5}$ & $\mathbf{1 2 . 9}$ & $\mathbf{1 5 . 7}$ \\
\hline \multicolumn{7}{|c|}{ Post-industrial area (Baia-Mare) } \\
\hline S7 & 22.5 & 31.2 & 70.0 & 0.30 & 41.2 & 44.4 \\
\hline S8 & 62.8 & 170 & 180 & 6.10 & 7.2 & 18.0 \\
\hline S9 & 35.0 & 38.4 & 89.2 & 1.00 & 31.6 & 52.2 \\
\hline S10 & 232 & 207 & 583 & 5.60 & 18.0 & 17.5 \\
\hline S11 & 27.2 & 277 & 321 & 2.70 & 1.80 & 22.5 \\
\hline S12 & 50.4 & 158 & 271 & 4.90 & 32.4 & 26.0 \\
\hline Minimum & $\mathbf{2 2 . 5}$ & $\mathbf{3 1 . 2}$ & $\mathbf{7 0 . 0}$ & $\mathbf{0 . 3 0}$ & $\mathbf{1 . 8 0}$ & $\mathbf{1 7 . 5}$ \\
\hline Maximum & $\mathbf{2 3 2}$ & $\mathbf{2 7 7}$ & $\mathbf{5 8 3}$ & $\mathbf{6 . 1 0}$ & $\mathbf{4 1 . 2}$ & $\mathbf{5 2 . 2}$ \\
\hline Average & $\mathbf{7 1 . 7}$ & $\mathbf{1 4 7}$ & $\mathbf{2 5 2}$ & $\mathbf{3 . 4 3}$ & $\mathbf{2 2 . 0}$ & $\mathbf{3 0 . 1}$ \\
\hline St. Dev. & $\mathbf{8 0 . 0}$ & $\mathbf{9 6 . 3}$ & $\mathbf{1 8 9}$ & $\mathbf{2 . 4 6}$ & $\mathbf{1 5 . 6}$ & $\mathbf{1 4 . 6}$ \\
\hline
\end{tabular}

The certified and measured results of certified reference materials (CRMs) together with the recovery degree are presented in Table 2. In accordance with Table 2, the results are in good agreement with the reference 
values of CRMs. The recovery degrees for the determination of metals in CRMs were in the range of $92-104 \%$ for soil and $92-100 \%$ for leafs. The HMs content in soil and plantain leafs collected from the urban and post-industrial areas is presented in Table 3 and Table 4.

The HMs concentration varies widely in the post-industrial soils, while in urban soils it is more homogenous. In the urban area, the alert values for sensitive soil use given by the Romanian legislation [16] are exceeded in 3 samples for $\mathrm{Pb}(50 \mathrm{mg} / \mathrm{kg}), 1$ sample for $\mathrm{Ni}(75 \mathrm{mg} / \mathrm{kg})$ and in 4 samples for $\mathrm{Cd}(1 \mathrm{mg} / \mathrm{kg})$. Hovewer, in none of the samples the corresponding intervention level is exceeded. In the post-industrial area, the alert values for sensitive use are exceeded in 1 sample for $\mathrm{Cd}$ and 3 samples for $\mathrm{Zn}(300 \mathrm{mg} / \mathrm{kg})$, while the intervention levels are exceeded in 4 samples for $\mathrm{Pb}(100 \mathrm{mg} / \mathrm{kg}), 1$ sample for $\mathrm{Cu}(200 \mathrm{mg} / \mathrm{kg})$ and 2 samples for Cd $(5 \mathrm{mg} / \mathrm{kg})$. In both areas the most abundant $\mathrm{HMs}$ are $\mathrm{Zn}$ and $\mathrm{Pb}$, but their average concentrations are two, respectively three times higher in the post-industrial area than in the urban area. The average content of $\mathrm{Cd}$ is comparable in the two areas, while the average $\mathrm{Cr}$ and $\mathrm{Ni}$ contents were higher in the urban area. The differences between the HMs concentrations in the two studied areas could be explained by the overlapping of industrial and urban pollution sources in the post-industrial Baia-Mare city, and the presence of urban pollution sources in Cluj-Napoca city. The average metal contents in soil decreases in the order $\mathrm{Zn}>\mathrm{Pb}>\mathrm{Ni}>\mathrm{Cr}>\mathrm{Cu}>\mathrm{Cd}$ in the soil of urban area, while in those of post-industrial area the decrease order is $\mathrm{Zn}>\mathrm{Pb}>\mathrm{Cu}>\mathrm{Ni}>\mathrm{Cr}>\mathrm{Cd}$, suggesting different metal pollution sources in the two studied areas. The average $\mathrm{Cu}, \mathrm{Pb}, \mathrm{Zn}$ and $\mathrm{Cd}$ contents in the post-industrial area are significantly lower than those reported by Levei et al. [17] for the same area in 2007, suggesting that environmental protection measures along natural attenuation and closing of the most pollutant industrial activities were effective in pollution reduction. Moreover, the pollution sources changes from the industrial (smelting) to urban areas (fuel and oil additives, tires, brake liners, urban surfaces corrosion or erosion). The found average HMs contents in the soils of post-industrial area are comparable for $\mathrm{Cd}$, higher for $\mathrm{Cu}$ and $\mathrm{Pb}$ and lower for $\mathrm{Zn}$ than those reported by NadgorskaSocha et al. [12] in soils from Dabrowa Gornicza city, Poland, where ironworks and waste processing plants function. The average concentrations of $\mathrm{Zn}$ are comparable, $\mathrm{Cd}$ and $\mathrm{Ni}$ higher and $\mathrm{Cu}$ and $\mathrm{Pb}$ lower in soils from ClujNapoca city, than those reported by Horvath et al. [18] in urban soils from Sopron city, Hungary.

Similarly to soil, the HMs concentration has a broader range in plantain leafs from the post-industrial area, than in those from the urban area. The average concentrations of $\mathrm{Pb}$ and $\mathrm{Zn}$ are much higher in the plantain leafs from post-industrial area, while the average concentrations of $\mathrm{Cu}, \mathrm{Cd}, \mathrm{Cr}$ 
and $\mathrm{Ni}$ are comparable in the two areas, indicating that plantain has a metal excluding mechanism that allows the tolerance of high contents of $\mathrm{Cu}, \mathrm{Cd}$, $\mathrm{Cr}$ and $\mathrm{Ni}$.

The contents of $\mathrm{Cu}, \mathrm{Pb}, \mathrm{Zn}$ found in plantain leafs from Cluj-Napoca were much lower than those found in Rome, Italy [10], while in leafs from Baia-Mare are considerably lower than those found in Kosovska Mitrovica city, Serbia, where a Pb and $\mathrm{Zn}$ smelter is operational [14]. Compared to HMs in Plantago lanceolata grown in soils from mining and smelting sites in the southern part of Poland [19], the contents of $\mathrm{Cd}, \mathrm{Pb}$ and $\mathrm{Zn}$ in the Plantago major leafs determined in our study in the post-industrial area were much lower, while those of $\mathrm{Cu}$ were higher.

Table 4. Heavy metal contents in plantain leafs $(\mathrm{mg} / \mathrm{kg})$

\begin{tabular}{|c|c|c|c|c|c|c|}
\hline Sample & $\mathrm{Cu}$ & $\mathbf{P b}$ & $\mathrm{Zn}$ & Cd & $\mathrm{Cr}$ & $\mathrm{Ni}$ \\
\hline \multicolumn{7}{|c|}{ Urban area (Cluj-Napoca) } \\
\hline P1 & 5.36 & 0.38 & 25.6 & 0.10 & 1.27 & 2.27 \\
\hline P2 & 7.21 & 0.10 & 17.9 & 0.21 & 3.35 & 3.35 \\
\hline P3 & 6.96 & 1.37 & 25.2 & 0.10 & 1.68 & 2.66 \\
\hline $\mathrm{P} 4$ & 9.51 & 0.39 & 40.7 & 0.14 & 0.82 & 3.93 \\
\hline P5 & 6.41 & 0.32 & 28.7 & 0.22 & 1.04 & 2.64 \\
\hline P6 & 7.46 & 0.37 & 20.9 & 0.07 & 1.02 & 2.47 \\
\hline Minimum & 5.36 & 0.10 & 17.9 & 0.07 & 0.82 & 2.27 \\
\hline Maximum & 9.51 & 1.37 & 40.7 & 0.22 & 3.35 & 3.93 \\
\hline Average & 7.15 & 0.49 & 26.5 & 0.14 & 1.53 & 2.88 \\
\hline St. Dev. & 1.38 & 0.45 & 7.93 & 0.06 & 0.94 & 0.63 \\
\hline $\mathbf{l j}$ & 5.20 & 1.10 & 3.34 & 2.25 & 1.63 & 4.60 \\
\hline \multicolumn{7}{|c|}{ Post-industrial area (Baia-Mare) } \\
\hline P7 & 6.61 & 0.54 & 32.6 & 0.06 & 0.42 & 2.51 \\
\hline P8 & 7.51 & 2.54 & 49.4 & 0.31 & 0.82 & 2.47 \\
\hline P9 & 5.91 & 0.97 & 26.0 & 0.11 & 1.07 & 1.86 \\
\hline P10 & 16.0 & 2.50 & 162 & 1.50 & 2.76 & 4.95 \\
\hline P11 & 11.1 & 3.07 & 52.9 & 0.11 & 0.33 & 1.10 \\
\hline P12 & 10.7 & 4.79 & 120 & 0.83 & 2.12 & 3.14 \\
\hline Minimum & 5.91 & 0.54 & 26.0 & 0.06 & 0.33 & 1.10 \\
\hline Maximum & 16.0 & 4.79 & 162 & 1.50 & 2.76 & 4.95 \\
\hline Average & 9.61 & 2.40 & 73.8 & 0.49 & 1.25 & 2.67 \\
\hline St. Dev. & 3.78 & 1.53 & 54.6 & 0.57 & 0.98 & 1.31 \\
\hline $\mathbf{l j}$ & 2.55 & 1.57 & 1.35 & 0.85 & 1.28 & 2.04 \\
\hline
\end{tabular}

The decreasing trend of the average HMs content is similar in the plantain leafs from post-industrial $(\mathrm{Zn}>\mathrm{Cu}>\mathrm{Ni}>\mathrm{Pb}>\mathrm{Cr}>\mathrm{Cd})$, and urban $(\mathrm{Zn}>\mathrm{Cu}>$ $\mathrm{Ni}>\mathrm{Cr}>\mathrm{Pb}>\mathrm{Cd}$ ) areas, except for $\mathrm{Pb}$ and $\mathrm{Cr}$. However, the decreasing trend is very different from that found in soil, suggesting that HMs concentration in plantain and soil does not vary proportionally, probably due to the different 
uptake mechanisms of individual HMs. A similar HMs order was found by Galal and Shehata [9] in plantain shoots grown in traffic polluted soils from the vicinity of Zagazig-Banha highway in Egypt. Except 1 sample for Zn, the HMs concentration in plantain leafs did not exceed the excessive or toxic concentrations: $20-100 \mathrm{mg} / \mathrm{kg} \mathrm{Cu}, 30-300 \mathrm{mg} / \mathrm{kg} \mathrm{Pb}, 100-400 \mathrm{Zn}, 10-100 \mathrm{Ni}$, 5-30 Cd and $\mathrm{Cr}[20]$.

To evaluate the plantain ability to take up HMs from soil, the enrichment factor (EF) was calculated according to equation 1. The EFs $>1$ indicate the plantain capacity to uptake HMs from soils and transfer them to leafs, EFs values near 1 suggest that the HMs content in plantain is not influenced by the HMs content in soil, while EFs $<1$ indicate that plantain exclude the HMs from uptake [9].

$$
E F_{j}=\frac{c_{p, j}}{C_{s}, j}
$$

where, $E F_{j}$ is the enrichment factor of a specific $H M, C_{p, j}$ is the $H M$ concentration in plantain leafs, expressed in $\mathrm{mg} / \mathrm{kg}$ and $\mathrm{C}_{\mathrm{s}, \mathrm{j}}$ is the $\mathrm{HM}$ concentration in soil, expressed in $\mathrm{mg} / \mathrm{kg}$.

The EFs (Table 5) are below 0.5 in both sites and for all investigated $\mathrm{HMs}$, the highest EF is found for $\mathrm{Zn}$ in the post-industrial site, probably as a consequence of the low HMs bioavailability or the development of exclusion mechanism in plantains grown on polluted substrate.

Table 5. Heavy metal enrichment factor in plantain leafs

\begin{tabular}{|c|c|c|c|c|c|c|}
\hline EF & Cu & Pb & Zn & Cd & Cr & Ni \\
\hline \multicolumn{7}{|c|}{ Urban area (Cluj-Napoca) } \\
\hline EF1 & 0.099 & 0.005 & 0.170 & 0.033 & 0.034 & 0.059 \\
\hline EF2 & 0.239 & 0.004 & 0.213 & 0.064 & 0.047 & 0.044 \\
\hline EF3 & 0.229 & 0.031 & 0.215 & 0.043 & 0.047 & 0.064 \\
\hline EF4 & 0.379 & 0.012 & 0.427 & 0.042 & 0.018 & 0.071 \\
\hline EF5 & 0.090 & 0.006 & 0.198 & 0.081 & 0.024 & 0.077 \\
\hline EF6 & 0.213 & 0.004 & 0.134 & 0.018 & 0.024 & 0.064 \\
\hline Minimum & $\mathbf{0 . 0 9 0}$ & $\mathbf{0 . 0 0 4}$ & $\mathbf{0 . 1 3 4}$ & $\mathbf{0 . 0 1 8}$ & $\mathbf{0 . 0 1 8}$ & $\mathbf{0 . 0 4 4}$ \\
\hline Maximum & $\mathbf{0 . 3 7 9}$ & $\mathbf{0 . 0 3 1}$ & $\mathbf{0 . 4 2 7}$ & $\mathbf{0 . 0 8 1}$ & $\mathbf{0 . 0 4 7}$ & $\mathbf{0 . 0 7 7}$ \\
\hline Average & $\mathbf{0 . 2 0 8}$ & $\mathbf{0 . 0 1 0}$ & $\mathbf{0 . 2 2 6}$ & $\mathbf{0 . 0 4 7}$ & $\mathbf{0 . 0 3 2}$ & $\mathbf{0 . 0 6 3}$ \\
\hline St. Dev. & $\mathbf{0 . 1 0 6}$ & $\mathbf{0 . 0 1 0}$ & $\mathbf{0 . 1 0 3}$ & $\mathbf{0 . 0 2 2}$ & $\mathbf{0 . 0 1 2}$ & $\mathbf{0 . 0 1 1}$ \\
\hline \multicolumn{7}{|c|}{ Post-industrial area (Baia-Mare) } \\
\hline EF7 & 0.294 & 0.017 & 0.466 & 0.200 & 0.010 & 0.057 \\
\hline EF8 & 0.120 & 0.015 & 0.274 & 0.051 & 0.114 & 0.137 \\
\hline EF9 & 0.169 & 0.025 & 0.291 & 0.110 & 0.034 & 0.036 \\
\hline EF10 & 0.069 & 0.012 & 0.278 & 0.268 & 0.153 & 0.283 \\
\hline EF11 & 0.408 & 0.011 & 0.165 & 0.041 & 0.183 & 0.049 \\
\hline EF12 & 0.212 & 0.030 & 0.443 & 0.169 & 0.065 & 0.121 \\
\hline Minimum & $\mathbf{0 . 0 6 9}$ & $\mathbf{0 . 0 1 1}$ & $\mathbf{0 . 1 6 5}$ & $\mathbf{0 . 0 4 1}$ & $\mathbf{0 . 0 1 0}$ & $\mathbf{0 . 0 3 6}$ \\
\hline Maximum & $\mathbf{0 . 4 0 8}$ & $\mathbf{0 . 0 3 0}$ & $\mathbf{0 . 4 6 6}$ & $\mathbf{0 . 2 6 8}$ & $\mathbf{0 . 1 8 3}$ & $\mathbf{0 . 2 8 3}$ \\
\hline Average & $\mathbf{0 . 2 1 2}$ & $\mathbf{0 . 0 1 8}$ & $\mathbf{0 . 3 2 0}$ & $\mathbf{0 . 1 4 0}$ & $\mathbf{0 . 0 9 3}$ & $\mathbf{0 . 1 1 4}$ \\
\hline St. Dev. & $\mathbf{0 . 1 2 3}$ & $\mathbf{0 . 0 0 8}$ & $\mathbf{0 . 1 1 4}$ & $\mathbf{0 . 0 8 9}$ & $\mathbf{0 . 0 6 8}$ & $\mathbf{0 . 0 9 2}$ \\
\hline
\end{tabular}


According to the EFs, the plantain's uptake capability is in the order $\mathrm{Zn}>\mathrm{Cu}>\mathrm{Ni}>\mathrm{Cd}>\mathrm{Cr}>\mathrm{Pb}$ in urban area and $\mathrm{Zn}>\mathrm{Cu}>\mathrm{Cd}>\mathrm{Ni}>\mathrm{Cr}>\mathrm{Pb}$ in postindustrial area. The similar trend confirms once again the exclusion capability of plantain that enables its tolerance to high levels of HMs allowing the colonization of highly contaminated soils. The EFs in the present study were lower compared to those reported in the Zagazig-Banha heavy-traffic highway, Egypt, comparable with those in Plantago lanceolata from a smelting area in Poland $[9,19]$. Compared to EFs reported in Urtica dioica from BaiaMare area our results are lower for $\mathrm{Cd}, \mathrm{Cr}$, Ni, higher for $\mathrm{Cu}$ and comparable for $\mathrm{Pb}$ and $\mathrm{Zn}$ [21]. Although plantain was reported as a good $\mathrm{Pb}$ and $\mathrm{Zn}$ accumulator [14], the study confirms the accumulation capacity for $\mathrm{Zn}$, but in case of $\mathrm{Pb}$ such capacity was not observed. A possible explanation could be either the low $\mathrm{Pb}$ bioavailability in soil or the fast adaptive tolerance of plantain to polymetallic pollution [22].

The range and average of EFs for the investigated elements in the two sites are presented in Figure 1.

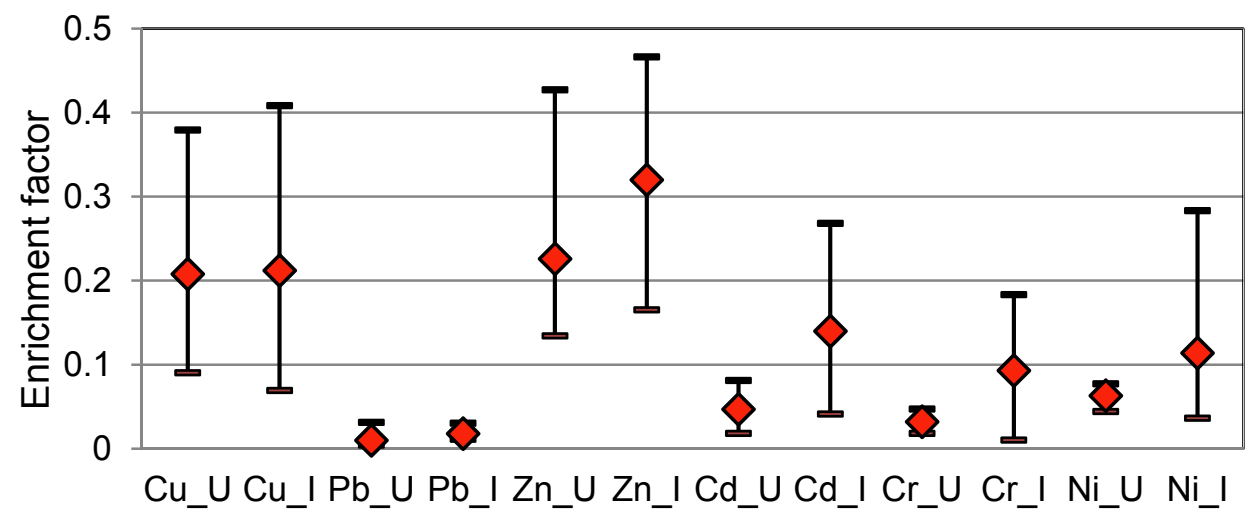

Figure 1. Range (min-max) and average EFs in urban $(U)$ and post-industrial $(I)$ areas

Although, generally low EFs were determined in the two sites, differences in terms of range and average can be noticed both among HMs and among sites. Thus, the $\mathrm{EFs}$ for $\mathrm{Cu}, \mathrm{Pb}$ and $\mathrm{Zn}$ have similar ranges in the two areas, a high variability being observed for $\mathrm{Cu}$ and $\mathrm{Zn}$. On the other hand, in the case of $\mathrm{Cd}, \mathrm{Cr}$ and $\mathrm{Ni}$, the ranges are wider in the postindustrial area than in the urban area. The average EFs in the two areas are comparable in case of $\mathrm{Cu}$ and $\mathrm{Pb}$ and higher in the industrial area for $\mathrm{Zn}, \mathrm{Cd}, \mathrm{Cr}$, Ni. Based on the enrichment factor, plantain was found to be tolerant to high $\mathrm{Cu}, \mathrm{Pb}, \mathrm{Zn}, \mathrm{Cd}, \mathrm{Cr}$ and $\mathrm{Ni}$ contents. 
To assess the HMs accumulation capability of plantain, metal accumulation index (MAI) was calculated according to Equation 2. Plants with high MAl are suitable to be used as barriers between contaminated and vulnerable areas, such as parks and residential areas [12, 23].

$$
M A I=\frac{1}{N} \sum_{j=1}^{N} I_{j}
$$

where $N$ is the number of metals determined (6) and $I_{\mathrm{j}}$ is the ratio of average concentration for each HMs in plantain leafs and its standard deviation.

The MAl for urban area is 3.02 , while for the post-industrial area is 1.61 , suggesting a moderate to good capability of plantain to accumulate metals from the surrounding environment. The contribution of each HM to MAI (Figure 2) revealed that in urban area the main accumulated elements are $\mathrm{Cu}, \mathrm{Ni}$ and $\mathrm{Zn}$, while in the post-industrial area $\mathrm{Cu}, \mathrm{Ni}$ and $\mathrm{Pb}$.
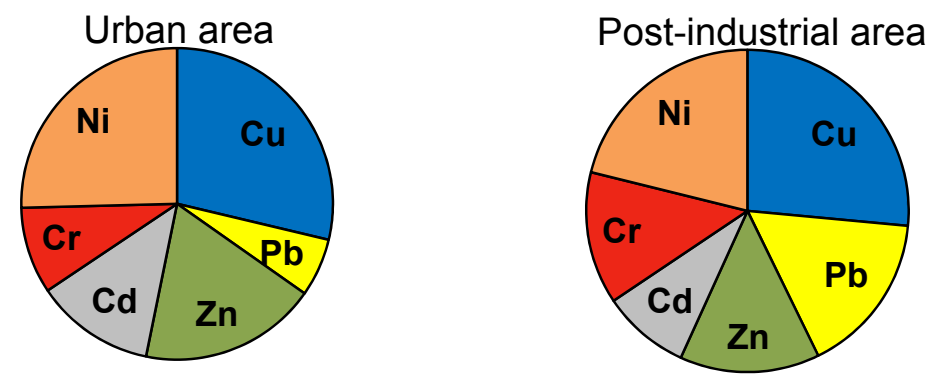

Figure 2. Heavy metal contribution to metal accumulation index (MAI)

The obtained MAI values were comparable with those of dandelion (Taraxacum officinale) grown in an area with intense traffic in Cuneo, Italy [23], but much lower than those of Plantago lanceolata grown in a smelting area from Poland [12].

\section{CONCLUSIONS}

This study was conducted to screen the Plantago major potential for heavy metal accumulation in soils from urban and post-industrial areas. The results of the study revealed significant differences between the contents of the analysed heavy metals in the soil and plantain leafs, of both urban and post-industrial areas. In both sites, $\mathrm{Zn}$ and $\mathrm{Pb}$ were the most abundant in soil, although the average concentrations of $\mathrm{Zn}$ and $\mathrm{Pb}$ were higher in the post-industrial area, while $\mathrm{Cr}$ and $\mathrm{Ni}$ in the urban area. The $\mathrm{Cu}, \mathrm{Cd}, \mathrm{Cr}$ and $\mathrm{Ni}$ in plantain leafs are comparable in the two areas, while 
$\mathrm{Pb}$ and $\mathrm{Zn}$ were higher in the post-industrial area. The soil-plantain enrichment factors below 0.5 in both sites and for all investigated metals indicated that Plantago major has developed an adaptive tolerance to heavy metal contaminated substrates. The metal accumulation index confirmed that plantain has a moderate to good capability to accumulate $\mathrm{Cu}$ and $\mathrm{Zn}$ from the surrounding environment.

\section{EXPERIMENTAL SECTION}

\section{Study species and areas}

Plantago major (plantain) is a member of the Plantaginaceae family, frequently found near roads, pastures, cultivated fields and landfills [9, 24]. It is a widely spread perennial herbaceous plant that thrives even in compacted soils with low water and nutrient contents. The oval-shaped, parallel-veined leafs with acute apex and smooth margin form a rosette. The flowers are small, greenish-brown with purple stamens, produced in a dense spike on top of a stem. The plant has medicinal applications since ancient times for wound healing, gastrointestinal disorders and respiratory infections [24]. Although an edible herb, rich in biological active compounds as flavonoids, vitamins $(\mathrm{A}, \mathrm{B}, \mathrm{C}, \mathrm{K})$ and micronutrients $(\mathrm{Cr}, \mathrm{Fe}, \mathrm{Mg}, \mathrm{Mn}, \mathrm{P}$, $\mathrm{K}, \mathrm{Se}, \mathrm{Si})$, it is considered more a weed than a foodstuff $[9,24]$.

Situated in the North-Western part of Romania, Cluj-Napoca is the fourth largest city, with about 350000 inhabitants. The main metal pollution sources are related to traffic, urban runoff, residential heating and municipal landfill [25, 26]. As a consequence of economic changes from heavy industry to services, the main industrial polluting sources have been removed progressively during the past decades. Situated in the North of Romania, Baia-Mare city has about 150000 inhabitants and was considered a pollution hotspot due to its long history of mining and ore processing activities [17]. The main pollution source is represented by the former metallurgical industry that produced base-metal ( $\mathrm{Pb}, \mathrm{Cu}, \mathrm{Zn}$ ) concentrates, Au and Ag from nonferrous sulfidic ores [27, 28]. In the last two decades both the extractive and metallurgical industry gradually declined. Currently all industrial activities are under conservation of decommissioned.

\section{Sampling, sample preparation and analysis}

Plantago major $(\mathrm{P})$ and the adjacent soil $(\mathrm{S})$ were collected at the end of their vegetative period (October 2016) in Cluj-Napoca urban (1-6) and BaiaMare post-industrial (7-12) areas in the North-West Romania. Leafs were collected using a Teflon coated knife. Leafs affected by chlorosis or necrosis were discarded. Plant leafs were thoroughly washed with tap water, rinsed three 
times with distilled water and freeze-dried using a FreeZone 2.5 freeze-drying system (Labconco) at $-40^{\circ} \mathrm{C}$ and -25 psi for 2 days. The dried samples were ground into a powder using GM200 Grindomix Knife Mill (Retsch). Soil samples were collected from root depth $(0-10 \mathrm{~cm})$ using a stainless steel scoop, air dried, ground to a fine powder and sieved through a $250 \mu \mathrm{m}$ sieve.

For sample preparation and analysis, certified standard solutions, high purity reagents (Merck) and ultrapure water (Direct-Q3 UV Millipore) were used. All glassware was cleaned with $5 \% \mathrm{HNO}_{3}$ prior to use. An amount of $1 \mathrm{~g}$ soil was exposed to acid digestion with $28 \mathrm{ml}$ aqua regia $(21 \mathrm{ml}$ of $37 \% \mathrm{HCl}$ and $7 \mathrm{ml}$ of $65 \% \mathrm{HNO}_{3}$ ) for $16 \mathrm{~h}$ at room temperature to produce slow oxidation of the organic matter, and then the temperature of the reaction mixture was raised to reflux conditions and maintained for $2 \mathrm{~h}$. After cooling to room temperature, the slurry was filtered and diluted to $100 \mathrm{ml}$ with distilled water. An amount of $1 \mathrm{~g}$ plantain powder was digested with $5 \mathrm{ml}$ of $65 \% \mathrm{HNO}_{3}$ and $2 \mathrm{ml}$ of $30 \% \mathrm{H}_{2} \mathrm{O}_{2}$ in a closed polytetrafluoroethylene vessel microwave digestion system (Berghof MWS-3+, Eningen, Germany) [29, 30]. The digested samples were filtered and diluted to $20 \mathrm{ml}$ with ultrapure water. The contents of $\mathrm{Cu}, \mathrm{Pb}, \mathrm{Zn}, \mathrm{Cd}, \mathrm{Cr}$ and $\mathrm{Ni}$ in the digested samples were determined by inductively coupled plasma mass spectrometry (Elan DRC II, Sciex, Perkin Elmer). The HMs concentration in both soil and leaf samples were measured in duplicate and the results were reported as average.

\section{Method performance and quality control}

The method performance was studied by determining the LOD, LOQ and $U$. The LOD of each element was calculated as the HMs concentration that corresponds to 3 times the standard deviation of ten independent measurements of the blank, divided by the slope of the calibration curve. The LOQ was calculated as 3 times the LOD [31, 32]. The $U$ was estimated by a bottom-up approach, systematically evaluating all the uncertainty sources from calibration certificates and from statistical analysis of repeated measurements. The combined standard uncertainty was obtained by combining the uncertainties, according to the law of propagation of uncertainties. The final result was reported as expanded uncertainty, calculated by multiplying the standard uncertainty with the coverage factor $(\mathrm{k}=2)$, corresponding to a $95 \%$ confidence level [33]. The accuracy of measurements was assessed by determination of the studied elements in ERM-CC141 Loam Soil and IAEA-359 Cabbage CRMs. 


\section{ACKNOWLEDGMENTS}

This work was supported by a grant of the Romanian National Authority for Scientific Research and Innovation, CCCDI - UEFISCDI, project number 91BM/2017 (IMPAACT).

\section{REFERENCES}

1. N. Massa, F. Andreucci, M. Poli, M. Aceto, M. Barbato, G. Berta, Ecotoxicology and Environmental Safety, 2010, 73, 1988.

2. S.M. Serbula, D.D.J. Milljkovic, R.M. Kovacevic, A.A. Ilic, Ecotoxicology and Environmental Safety, 2012, 76, 209.

3. H. Ali, E. Khan, Toxicological \& Environmental Chemistry, 2018, DOI: 10.1080/ 02772248.2017.1413652.

4. O. Pourret, J.C. Bollinger, Science of the Total Environment, 2018, 610-611, 419.

5. K.J. Appenroth, Acta Physiologiae Plantarum, 2010, 32, 615.

6. A. Gholizadeh, L. Boruvka, M.M. Seberioon, J. Kozak, R. Vasat, K. Nemecek, Soil and Water Research, 2015, 10, 218.

7. F.J. Zao, European Journal of Soil Science, 2010, 61,155.

8. G. Lough, J.J. Schauer, J.S. Park, M.M. Shafer, J.T. Deminter, J. Weinstein, Environmental Science \& Technology, 2005, 39, 826.

9. T.M. Galal, H.S. Shehata, Ecological Indicators, 2015, 48, 244.

10. D. Malizia, A. Giuliano, G. Ortaggi, A. Masotti, Chemistry Central Journal, 2012, 6, S6.

11. M. K. Kurteva, Phytologia Balcanica, 2009, 15, 261.

12. A. Nadgorska-Socha, M. Kandziora-Ciupa, M. Trzesicki, G. Barczyk, Chemosphere, 2017, 183, 471.

13. A.A. Akram, A.A. Al-Homaidan, Australian Journal of Basic and Applied Sciences, 2007, 1, 467.

14. R. Filipovic-Trajkovic, Z.S. Ilic, L. Sunic, S. Andjelkovic, Journal of Food, Agriculture \& Environment, 2012, 10, 959.

15. R. Djingova, I. Kuleff, Chemistry and Ecology, 1999, 16, 239.

16. Ministerial Order 956, Official Journal of Romania, 1997, 303bis

17. E. Levei, T. Frentiu, M. Ponta, M. Senila, M. Miclean, C. Roman, E. Cordos, International Journal of Environmental Analytical Chemistry, 2009, 89, 635.

18. A. Horvath, P. Szucs, A. Bidlo, Journal of Soils and Sediments, 2015, 15, 1825.

19. A. Nadgorska-Socha, B. Ptasinski, A. Kita, Ecotoxicology, 2013, 22, 1422.

20. Kabata-Pendias, A., "Trace Elements in Soils and Plants" Fourth ed. CRC Press, Boca Raton, FL. 2010, chapter 5.

21. C. Mihali, G. Oprea, A. Michnea, S.G. Jelea, M. Jelea, C. Man, M. Senila, L. Grigor, Carpathian Journal of Earth and Environmental Sciences, 2013, 8, 143. 
22. E. Remon, J.L. Bouchardon, O. Faure, Chemosphere, 2007, 69, 41-47.

23. A. Giacomino, M. Malandrino, M.L. Colombo, S. Miaglia, P. Maimone, S. Blancato, E. Conca, O. Abollino, Journal of Chemistry, 2016, 2016, 9842987.

24. J. Vandana, A.K. Gupta, A. Mukerjee, International Journal of Chemical and Physical Sciences, 2017, 6, 26.

25. C. Florean, H. Szilagyi, A. Hegy, Present Environment and Sustainable Development, 2016, 10, 207.

26. N. Bican-Brisan, T. Enache, C. Rosu, Studia UBB Chemia, 2013, 63, 253.

27. C. Roba, C. Rosu, I. Pistea, A. Ozunu, C. Baciu, Environmental Science and Pollution Research, 2016, 23, 6062.

28. M. Senila, E.A. Levei, L.R. Senila, G.M. Oprea, C.M. Roman, Journal of Environmental Science and Health, Part A: Toxic/Hazardous Substances and Environmental Engineering, 2012, 47, 614.

29. E. A. Levei, M. Miclean, M. Senila, Studia UBB Chemia, 2012, 62, 103.

30. O. Cadar, M. Miclean, S. Cadar, C. Tanaselia, L. Senila, M. Senila Environmental Engineering and Management Journal, 2015, 14, 2523.

31. C. Voica, A. Dehelean, A. loardache, I. Geana, Romanian Reports in Physics, 2012, 64, 221.

32. T. Frentiu, M. Ponta, R. Hategan, Chemistry Central Journal, 2013, 7, 43.

33. M. Senila, A. Drolc, A. Pintar, L. Senila, E. Levei, Journal of Analytical Science and Technology, 2014, 5, 37. 